\title{
National Mineral Waste Databases as an Information Source for Assessing Material Recovery Potential from Mine Waste, Tailings and Metallurgical Waste
}

\author{
Gorazd Žibret ${ }^{1, * \mathbb{C}}$, Bruno Lemiere ${ }^{2}$, Ana-Maria Mendez ${ }^{3}$, Carlo Cormio ${ }^{4}\left(\mathbb{D}\right.$, Danielle Sinnett ${ }^{5}$, \\ Peter Cleall ${ }^{6}$, Katalin Szabó ${ }^{7}$ and M. Teresa Carvalho ${ }^{8}$ \\ 1 Department of Mineral Resources and Geochemistry, Geological Survey of Slovenia, Dimičeva ulica 14, \\ SI-1000 Ljubljana, Slovenia \\ 2 BRGM, F-45060 Orléans, France; b.lemiere@brgm.fr \\ 3 Mines and Energy School, Technical University of Madrid, 28004 Madrid, Spain; anamaria.mendez@upm.es \\ 4 SERENGEO Srl, Via A. Costa 165, 40134 Bologna, Italy; c.cormio@serengeo.com \\ 5 Centre for Sustainable Planning and Environments, University of the West of England, BS16 1QY Bristol, UK; \\ Danielle.Sinnett@uwe.ac.uk \\ 6 School of Engineering, Cardiff University, CF10 3AT Cardiff, UK; cleall@cardiff.ac.uk \\ 7 Mining and Geological Survey of Hungary, Columbus utca 17-23, 1590 Budapest, Hungary; \\ szabo.katalin@mbfsz.gov.hu \\ 8 CERENA, DECivil, Instituto Superior Técnico, Universidade de Lisboa, Av. Rovisco Pais, 1049-001 Lisboa, \\ Portugal; teresa.carvalho@tecnico.ulisboa.pt \\ * Correspondence: gorazd.zibret@geo-zs.si
}

Received: 27 March 2020; Accepted: 14 May 2020; Published: 16 May 2020

\begin{abstract}
We examined the national mine waste registries from seven European countries, created to fulfil the requirements of the "Mine Waste Directive" (2006/21/EC), for their potential use as an initial source of information for the valorisation of specific mine waste deposits for their resource recovery. A set of parameters for mine waste valorisation was defined and divided into three groups: the "basic", the "metal-centric" and the "material-centric" group. The "basic" group of 19 parameters considers properties of the mine waste deposit, including the location, history, homogeneity and quantity, among others, while the other two groups relate to the two desired material recovery types. The "metal-centric" group of parameters contains the six parameters needed to preliminarily assess the potential to valorise mine waste for metal extraction, while the "material-centric" group contains the nine parameters needed to consider the use of mine waste for the production of different construction materials. National mine waste registries from Slovenia, France, Spain, Italy, UK, Hungary and Portugal were reviewed to determine whether they contain information about each of the parameters. In line with the objectives of the Mine Waste Directive, the national mine waste registries were developed to reduce or prevent environmental damage, and not to enable resource recovery from mine waste. The registries contain most of the information for the parameters in the "basic" group, less information for the parameters in the "metal-centric" group and almost no information to define the parameters in the "material-centric" group. The conclusion is that national mine waste registries could serve only as an initial source of information, and more detailed information must be obtained from other sources. This misses an opportunity to see these sites as a resource, and not only as a potential source of pollution, given the urgent need to find alternative stocks of metals within the EU (European Union).
\end{abstract}

Keywords: tailings; mining; resource recovery; construction materials; metals; raw materials 


\section{Introduction}

The global mining industry is facing several challenges today. For example, the decreasing average grade of mined ore, and the inaccessibility of the deposits, whether being in areas unfavourable for humans to work (i.e., ultra-deep deposits, under the sea, etc.) or where current land use prevents mining. The latter, especially, limits the development of the European mining industry in many countries. Although the mining industry in Europe has been declining over the last few decades, Europe has a long-lasting mining tradition. The oldest mines in Europe are more than 5000 years old, and a golden age for mining was the period of industrial revolution in 19th century [1]. However, due to the economic and environmental pressures, many mines in Europe have been closed down in the 19th and 20th century, and their legacy are, among others, mined waste rock (the material that is extracted but not processed, mine spoils, overburden), low grade stockpiles, tailings (material rejected during mineral processing) and metallurgical waste deposits (slags). In this paper, all these types of waste are generally classified as "mine waste".

Mineral processing and metallurgical technology in the past were not as efficient as they are today. What was regarded as waste in the past can often be regarded as quality ore today. For example, Mudd [2] reported that the average grade of mined Cu ore in Australia was 15\%-25\% from 1842 to 1880, and then gradually decreased to around 4\% between 1880 and 1940, dropping to around 2\% by 2008, while during this time, the production of $\mathrm{Cu}$ ore and waste rock were steadily increasing. Today, the largest $\mathrm{Cu}$ open pit mines can economically extract $\mathrm{Cu}$ ores below 1\%. A similar pattern is also observed for Au. In Australia, ores with 15-30 g/t Au were extracted during 1850 to 1910, dropping to around 15 g/t during 1910 to 1940 and steadily decreasing to 1-2 g/t in 2008 [2]. In addition, current technologies require a greater variety of raw materials than were needed in the past. In ancient times, from the Bronze Age to the beginning of Medieval times, only seven metals were required to meet human needs ( $\mathrm{Fe}, \mathrm{Cu}, \mathrm{Ag}, \mathrm{Sn}, \mathrm{Au}, \mathrm{Hg}$ and $\mathrm{Pb}$ ), with an additional five ( $\mathrm{Zn}, \mathrm{As}, \mathrm{Sb}, \mathrm{Pt}$ and $\mathrm{Bi}$ ) being required in Medieval times. Today, almost every naturally occurring element in the periodic table is needed in order to produce all types of goods used by society [3]. This means that many elements needed to produce new technologies, electronic devices, green technologies, computing, etc., were completely disregarded even 50-60 years ago and were deposited as mine wastes (Figure 1). Prime examples are semiconductors (e.g., Ge and Ga), rare earth elements (e.g., Ce, Nd, Eu, Er and Lu) or so-called energy elements, needed for batteries (graphite, Co, Li) [4]. The American Chemical Society [5] has also presented a similar list of endangered and critical elements. Elements in this list are grouped into three groups: those which could face limited availability due to future risks to supply (28 elements), those for which supply is at risk due to increased use (7 elements) and finally elements for which future supply is predicted to be at serious risk in the next 100 years (9 elements). The EU (European Union) also published its own list of critical raw materials [6], and this list is regularly updated. The 2017 list contains 27 different non-energy raw materials because risks of their supply shortage and their impacts on the EU economy are higher than those of the other raw materials.

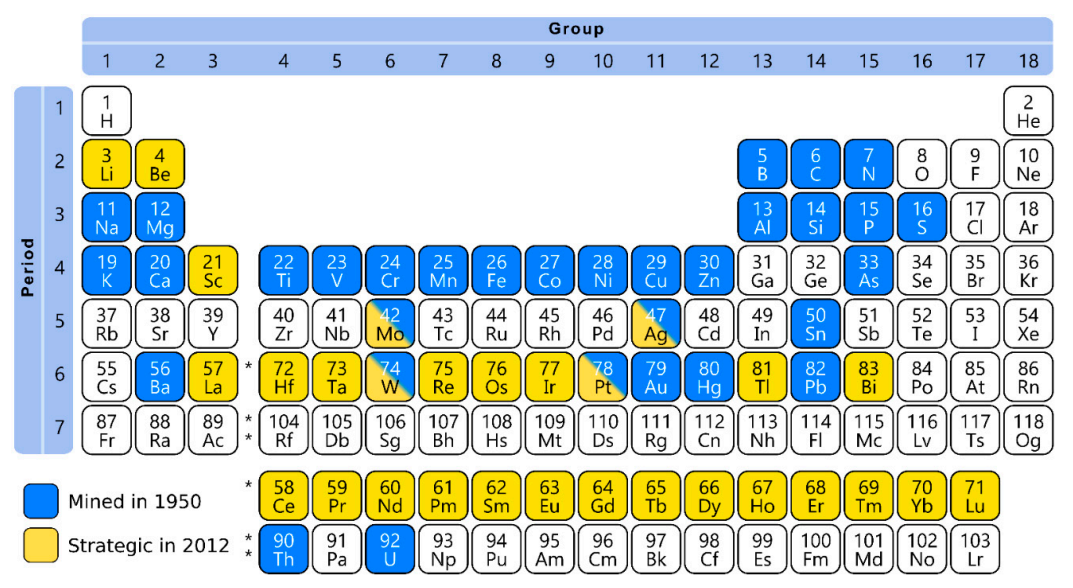

Figure 1. The need of minerals through time (adapted from [7]). 
Very efficient mineralogical, pyrometallurgical and hydrometallurgical processes have been developed for the recovery of metals from low-grade ores and wastes in the last two decades [8-11], such as in situ leaching, dump and heap leaching, hydrometallurgical processes and agromining, among others. An alternative area of development has been in relation to contaminated land remediation technologies, and Sapsford et al. [12] offer a review of many of these approaches and assess their limitations and constraints and technology status. One method of particular interest is the application of electrokinetic techniques, which have potential applicability to the fine-grained materials often found in mine waste deposits. Peppicelli et al. [13] have published the results of an experimental study of the changes in metal speciation and mobility during the electrokinetic treatment of industrial wastes. They also consider the implications of this approach in terms of remediation and resource recovery, noting that this type of approach has the potential to convert waste materials into assets by transforming them into viable ore deposits [13].

It is evident that some old abandoned mine waste deposits could be increasingly relevant as sources for raw materials [14], and some of them could, by today's standards, be considered as low-grade ores. Their easy access (located on the surface without significant overburden), already crushed (no need for primary crushing) and potentially contained ore grades, which can today be economically exploited, makes them interesting materials for the possible future valorisation for resource recovery. If located close to consumption centres, such materials can also potentially be used in construction or as a source for the production of construction materials [15]. These deposits are usually located next to historic mines, where the natural environment has undergone many changes in the past and can pose a potential source for the future dispersion of pollutants into the environment. Therefore, there may be an advantage in combining resource recovery from mine waste deposits with site rehabilitation processes. This has also been recognised by the EU, funding several projects dealing with material recovery from mine wastes whether, for example, through the Horizon 2020 programme (i.e., Smart Ground or Remediate projects) or the EIT (The European Institute of Innovation \& Technology) RawMaterials network (RIS-RECOVER, RIS-CuRE, RIS-ALiCE and many others).

However, little is generally known about the physical and chemical characteristics of mine wastes, particularly in older deposits. The same is true for their composition below the surface, homogeneity and any secondary processes following deposition. The lack of reliable data about these deposits, combined with the ambiguity in many countries regarding which legislation takes precedence for resource recovery from mine waste deposits (i.e., mineral extraction, waste management, environmental protection, planning, etc.) seems to present a barrier to their large-scale reuse. In order to examine the potential for resource recovery from mine waste, it is therefore essential that a detailed understanding of the composition and properties of these wastes are developed first.

One potential source of the composition data and properties of mine wastes is the inventory of mine waste deposits available for each EU member state. They have been produced according to the EU Directive 2006/21/EC [16] (often referred to as "The Mine Waste Directive"). This directive was a response to two large environmental disasters caused by improper tailings management, the Aznalcollar tailing dam collapse (Spain, 1998) [17,18] and the Baia Mare cyanide spill (Romania, 2000) [19], and one of its principal aims is to prevent similar disasters in the future. According to Article 20 of this directive, all EU member states are obliged to produce an inventory of closed and abandoned (mine) waste facilities which cause or have a potential to cause serious negative environmental impacts or pose a threat to humans. Such inventories are required to be updated regularly and made publicly available from 1 May 2012.

Another EU document published in 2008 details the Raw Materials Initiative (COM(2008)699) [20]. This document was not directly linked to the previously mentioned 2006/21/EC directive [16], and was adopted as a response to a perceived potential global threat to the uninterrupted supply of mineral resources which are vital for the EU's economic development. This initiative defines three pillars regarding the sustainable supply of raw materials for the EU economy: a fair and sustainable supply from global markets, a sustainable supply from within the EU and a resource efficiency and sustainable 
supply from secondary raw materials through recycling. This paper addresses the last pillar of the Raw Materials Initiative because the recycling of old and abandoned mine waste deposits, which are abundant within the EU due to a long-lasting mining tradition, could be an interesting source of raw materials for the EU economy. However, before actual mine waste recycling projects can be undertaken, many steps are required, the first of which consists of collecting basic information about individual mine waste deposits.

Therefore, the main objective of this study is to review a sample of national mine waste inventories, and to provide an assessment of their suitability as an initial source of data for potential resource recovery projects, while a secondary objective of this study is to define the set of most important mine waste valorisation parameters, which could be potentially contained within the abovementioned registries. This information will be useful to policy makers who will benefit from an improved understanding of the most critical national mine waste valorisation data gaps and determine steps forward, while the metallurgical and extractive industry will benefit from an initial assessment of the data availability for a set of EU countries to obtain information about the potential for resource recovery from mine wastes.

\section{Materials and Methods}

The materials used in the study were gathered by a literature review, information collected in the extractive waste inventories of seven EU member states, listed in Table 1 (France, Hungary, Italy, Portugal, Slovenia, Spain and UK; this study was conducted in the period between 2017-2019, when the UK was still the European Union member state) and enquiries to different experts in public and private institutions. These countries were chosen to offer coverage of a range of varying geological conditions, geographical locations and mining legacies in the EU. The work was carried out in the European Cooperation in Science and Technology (COST) action Mining the European Anthroposphere (MINEA), working group 2.1 (WG2.1) — “Resource potential in residues from extractive industries". The steps conducted in this research are presented schematically in Figure 2 and are described in more detail in Sections 2.1 and 2.2.

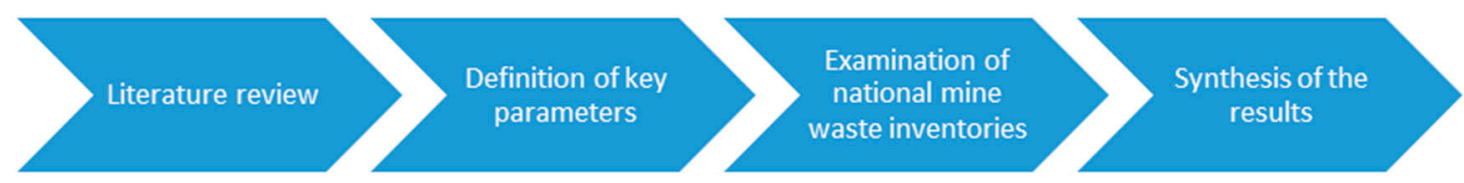

Figure 2. Methodological approach and the different steps conducted in this study.

\subsection{Defining Key Mine Waste Valorisation Data Parameters}

In order to evaluate the use of national mine waste inventories as a source of data, it was necessary to define the parameters of mine wastes that would be needed to understand their potential for resource recovery. This objective was achieved through a literature review, workshops and review of best practices. A final list was then formulated and refined by experts in the COST action MINEA, WG2.1. The literature review included academic, policy and practice literature, and examples from actual material recovery projects, which were used to develop an initial list of the parameters used to valorise the mineral resources. A key study identified was presented by Panagiotopoulou et al. [21], who describe several cases of material recovery from mine waste within the EU and defined the most crucial steps from the idea towards realisation. Other publications used for the literature review were different key reports from the topic [7,14,22-26], as well as CRIRSCO [27], JORC [28], PERC [29] and UNECE [30] classification codes for reporting the exploration results, mineral resources and reserves and the references contained in the aforementioned documents. The parameters identified included those related to basic site and commodity information, historical framework, data collection methodology, extractability and accessibility of the secondary resources, the policy and legislative environment, as well as the relevant chemical and physical properties. By accessibility we mean if there are any legal, environmental or societal obstacles for a material recovery project, and by extractability 
we mean whether the material can be extracted and reallocated without posing a serious risk to workers and the environment. The initial list of parameters was further evaluated and refined by between 40 and 50 experts from the fields of mining, geosciences, material processing and others, who participated in a series of workshops, organised or co-organised by the authors of this study and funded by the MINEA network: Ljubljana (23-24 February 2017), Vienna (14-15 December 2017) and Budapest (26-27 November 2018) working group meetings; the workshop/conference "Knowledge base for material resources/reserves for construction and demolition waste, landfills and waste incineration residues recovery" (Prague, 24-25 January 2019); the workshop "Knowledge base for anthropogenic resource and reserve estimates II" (Brussels, 20 March 2019); and the conference "Recovery of secondary raw materials from mining residuals and waste, case studies and best practices" (Berlin, 23 May 2019). During the meetings and workshops, this list was supplemented with data from case studies of resource recovery from mine waste in the EU and globally, with an emphasis on the experiences from different cases from Greece (e.g., Kassandra, Kirki, Lavrion, Tsagli, Domokos, Zidanio, Mantoudi mining areas and others) and from projects identified as relevant by the French Geological Survey BRGM (Pinto Valley, Arizona, USA; Disputada Mine, Chile; Kaltails Project, Australia; Kasese, Uganda, and others). This process resulted in the final list of the key mine waste valorisation parameters presented in this paper.

\subsection{Review and Assessment of National Mine Waste Inventories}

We carefully examined national mine waste inventories (made according to the EU directive 2006/21/EC obligations [16]) to ascertain the availability of the key data parameters for a preliminary assessment of the resource recovery potential of specific mine wastes. Major data gaps in the critical information for deposit ranking were identified and according to the findings' recommendations were made, to assist a collection of initial information needed for mine waste resource recovery projects in the future. Seven member states' national inventories were reviewed (Table 1) and were compared against the list of parameters needed to evaluate the potential for resource recovery, and, where necessary, experts from national authorities responsible for the inventories were consulted to supplement the review (Table 1).

\section{Results and Discussion}

A set of key mine waste valorisation parameters for material recovery were divided into three groups using an approach similar to that presented in Panagiotopoulou et al. [21]. The "basic" group of parameters describes the characteristics related to the mine waste deposit, i.e., the location, type of material, data collection methods, history of mine, etc., as well as the main drivers and barriers for resource recovery, e.g., legislation, land use restrictions, the availability of data, etc. (Table 2). The "metal-centric" group includes crucial information about the properties of mine waste material that should be considered to further extract valuable minerals/metals. The chemical and mineralogical composition of the mine waste defines the potential metallurgical or chemical extraction process, while the physico-chemical properties mainly define the pre-processing activities (drying, grinding, additives, homogenisation, separation, etc.) needed before the commodity extraction. Finally, the "material-centric" group describes the key parameters required to assess the feasibility of using mine waste for products for the construction sector. The parameters describing the composition of the material allow us to define the materials' ability to form clinker minerals and other binding agents during the production process, as well as the needs of specific additives. Parameters related to the physico-chemical properties allow us to estimate the costs and equipment needed to pre-process the source material (grinding, separation, screening, etc.). The determination of the physical and chemical properties of the potential end-products allows the assessment of the economic viability of resource recovery. 
Table 1. Responsible organisation for preparing and keeping the National mine waste registries and basic information about the registries.

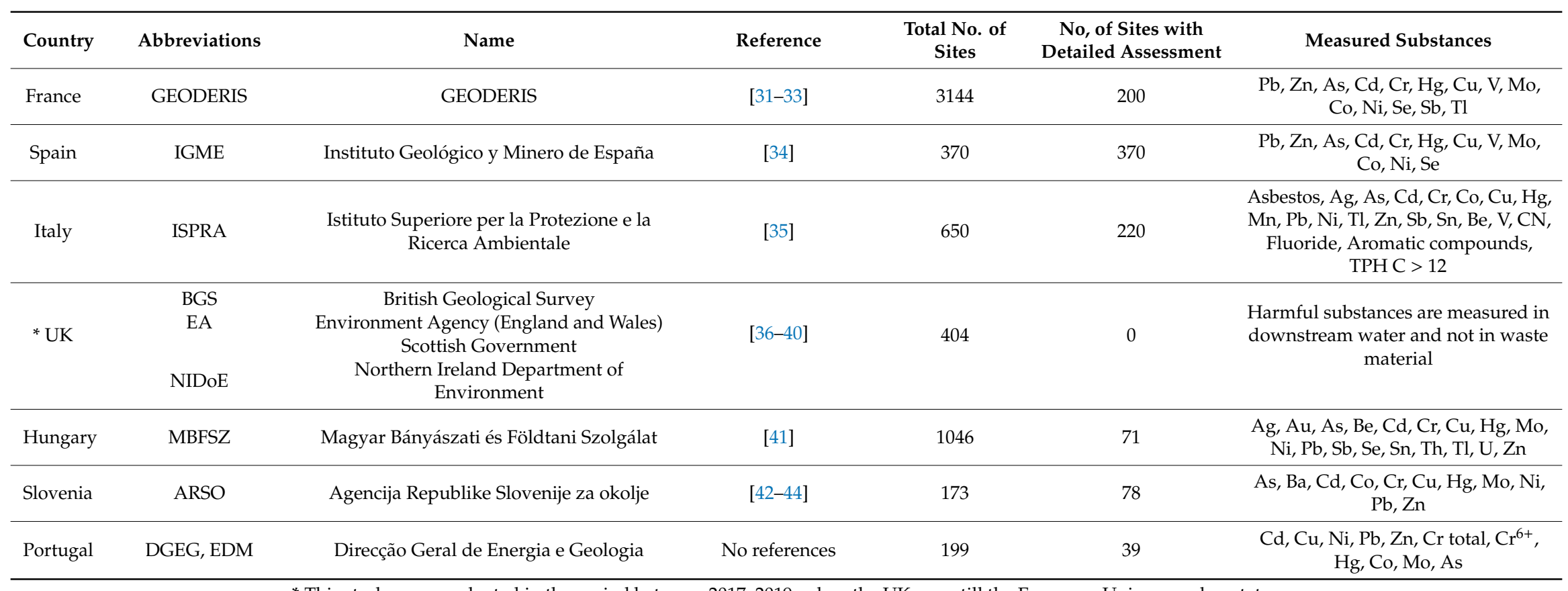

* This study was conducted in the period between 2017-2019, when the UK was still the European Union member state. 
Table 2. Key identified mine waste valorisation parameters.

\begin{tabular}{|c|c|c|c|}
\hline & Parameter ID & Short Description & Sub Division \\
\hline \multirow{9}{*}{$\begin{array}{c}\text { Basic Valorisation } \\
\text { Parameters }\end{array}$} & B1 & $\begin{array}{l}\text { Location, history, mining } \\
\text { and processing } \\
\text { technology of the site }\end{array}$ & \\
\hline & B2 & $\begin{array}{l}\text { Volume, area and } \\
\text { structure of the existing } \\
\text { waste deposits }\end{array}$ & \\
\hline & B3 & $\begin{array}{l}\text { Reason for which the } \\
\text { mine was abandoned }\end{array}$ & \\
\hline & B4 & $\begin{array}{l}\text { Homogeneity of the } \\
\text { tailings }\end{array}$ & \\
\hline & B5 & $\begin{array}{l}\text { Methodology of data } \\
\text { collection }\end{array}$ & \\
\hline & $\begin{array}{l}\text { B6.1 } \\
\text { B6.2 } \\
\text { B6.3 } \\
\text { B6.4 } \\
\text { B6.5 } \\
\text { B6.6 }\end{array}$ & $\begin{array}{l}\text { Environmental impacts } \\
\text { of mine waste deposit }\end{array}$ & $\begin{array}{l}\text { Actual physical } \\
\text { Potential physical } \\
\text { Actual chemical } \\
\text { Potential chemical } \\
\text { Need for remediation } \\
\text { Remediation costs }\end{array}$ \\
\hline & $\begin{array}{l}\text { B7.1 } \\
\text { B7.2 }\end{array}$ & Site extractability & $\begin{array}{c}\text { Possibility for safe extraction and waste } \\
\text { relocation } \\
\text { Revegetation status }\end{array}$ \\
\hline & $\begin{array}{l}\text { B8.1 } \\
\text { B8.2 } \\
\text { B8.3 } \\
\text { B8.4 }\end{array}$ & Site accessibility & $\begin{array}{l}\text { Ownership } \\
\text { Special permits required } \\
\text { Land use restrictions } \\
\text { Other legislative barriers }\end{array}$ \\
\hline & $\begin{array}{l}\text { B9.1 } \\
\text { B9.2 }\end{array}$ & Data availability & $\begin{array}{l}\text { Data managing authority } \\
\text { Language(s) }\end{array}$ \\
\hline \multirow{2}{*}{$\begin{array}{l}\text { Metal-Centric } \\
\text { Valorisation Parameters }\end{array}$} & $\begin{array}{l}\text { M10.1 } \\
\text { M10.2 } \\
\text { M10.3 }\end{array}$ & $\begin{array}{l}\text { Chemical and } \\
\text { mineralogical } \\
\text { composition }\end{array}$ & $\begin{array}{c}\text { Matrix } \\
\text { Commodity elements } \\
\text { Trace elements }\end{array}$ \\
\hline & $\begin{array}{l}\text { M11.1 } \\
\text { M11.2 } \\
\text { M11.3 }\end{array}$ & $\begin{array}{l}\text { Physico-chemical } \\
\text { properties }\end{array}$ & $\begin{array}{c}\text { Grain size distribution } \\
\text { Moisture content } \\
\text { Redox state at different } \mathrm{pH}\end{array}$ \\
\hline \multirow[t]{3}{*}{$\begin{array}{c}\text { Material-Centric } \\
\text { Valorisation Parameters }\end{array}$} & $\begin{array}{l}\mathrm{C} 10.1 \\
\mathrm{C} 10.2 \\
\mathrm{C} 10.3 \\
\mathrm{C} 10.4 \\
\mathrm{C} 10.5\end{array}$ & $\begin{array}{l}\text { Chemical and } \\
\text { mineralogical } \\
\text { composition }\end{array}$ & $\begin{array}{c}\text { Type and content of alkali ions } \\
\text { Type and content of alkaline earth ions } \\
\text { Type and content of silicon } \\
\text { Type and content of potentially toxic } \\
\text { elements (PTEs) } \\
\text { Type and content of organic substance }\end{array}$ \\
\hline & $\begin{array}{l}\mathrm{C} 11.1 \\
\mathrm{C} 11.2\end{array}$ & $\begin{array}{l}\text { Physico-chemical } \\
\text { properties }\end{array}$ & $\begin{array}{c}\text { Moisture } \\
\text { Grain size distribution }\end{array}$ \\
\hline & $\begin{array}{l}\mathrm{C} 12.1 \\
\mathrm{C} 12.2\end{array}$ & $\begin{array}{l}\text { Potential final products } \\
\text { specifications }\end{array}$ & $\begin{array}{l}\text { Mechanical properties } \\
\text { Thermal properties }\end{array}$ \\
\hline
\end{tabular}

During the reviewing of the national mine waste registries, we identified two special cases. Firstly, in Italy, the data for the number of sites with a detailed assessment (Table 1) included sites from the whole country which had been subjected to either research projects, or had been reclaimed (completed or ongoing), and all Sardinian sites (data published in 2017 registry update) which had been subjected to an additional assessment. In 2009, Sardinia region developed the so-called A.R.A.G.N.A. method (Relative Risk Analysis of Abandoned mining sites in Sardinia) which was applied to Sardinian mining sites. The method provides detailed instructions concerning the sampling procedures and methods, data processing, characterisation, etc. The method has been developed for risk assessment, thus there is a lack of information about minerals and elements that could be of industrial interest. Detailed information is not available in the report published by ISPRA (Italian Institute for Environmental 
Protection and Research), who is responsible for Italian mine waste registry. Secondly, four different authorities are managing the mine waste registry in the UK, with each one responsible for a specific geographic region, thus they also used slightly different risk assessment methodologies. The Northern Ireland risk assessment measured downstream water and sediment quality from sites mined for bauxite, copper, iron ore, lead, coal, lignite and baryte, but no detailed assessment of wastes themselves have been made. The risk assessment was based on the use of hazard quotients, and As, $\mathrm{Cd}, \mathrm{Cr}, \mathrm{Cu}, \mathrm{Fe}$, $\mathrm{Ni}, \mathrm{Pb}$ and $\mathrm{Zn}$ have been tested. In Scotland, England and Wales, the risk assessment was based on the elevated metal concentrations in water catchments and known locations of mines, supplemented with local authority information which identified additional sites to be included due to the explosive risk or instability.

The key valorisation parameters' availabilities in the reviewed national mine waste registries are shown in Table 3 ("basic" group), Table 4 ("metal-centric" group) and Table 5 ("material-centric" group). The analysis of the information in Table 3 shows that the main objective of creating national mine waste inventories was to decrease their potential and actual environmental hazard and impact, with the aim of determining the specific tailings in most urgent need of remediation, and only to a lesser extent for their potential for resource recovery in the future (Figure 3a).

Mine waste deposits were generally classified according to their potential for further mobilisation of harmful substances to deposits where there is no or low risk, and deposits of higher risk. Higher risk sites were then assessed in greater detail (Table 1) and, as a result, have more data available. This approach was taken by the majority of countries (Figure 3b). However, the exceptions are Spain, where only larger deposits were assessed, and UK, where detailed information about specific mine waste deposits are not contained in the national mine waste inventory, but instead in other databases and reports collected on an ad-hoc basis. This demonstrated that national mine waste inventories are generally an incomplete and inconsistent data source for the mine waste valorisation for material recovery. The most useful information contained in the inventories are the location of the deposit, the general description of the material and the estimated quantity of such a material, while the detailed assessment of individual deposits focused more on environmental parameters (i.e., concentrations of potentially toxic elements (PTEs) and the results of leaching tests, sediment mobilisation or similar). It is apparent that only Italy and Spain have more comprehensive information regarding all the listed mining sites in the inventory. In France, Hungary and UK, the amount of data for each site is predominantly linked with assessment of the site's environmental risk. In the UK, the environmental risk determination was based by the presence of receptors, and therefore is not necessarily an indication of the concentrations of metals in the wastes; there are thousands of abandoned metal mines in England and Wales, yet only around 150 in the inventory [39]. In Slovenia, the size of sites was the most relevant parameter (others parameters are linked to the specific type of mine waste), determining a further data gathering protocol, and in Portugal, the data availability is limited to the remediated and active sites.

Another important factor is the local policies and regulations pertaining to resource recovery from mine waste, which is also almost completely disregarded in the national inventories. One very important aspect is the ownership of the tailings (i.e., state, county, municipality, private entity, etc.), as well as the indication of key legislations and policies, which regulate mine waste exploitation and processing (i.e., mining legislation, spatial planning at national and local level, environmental protection, waste management, etc.). Currently, it seems that many relevant regulations apply, including those related to mineral extraction, waste management, land use planning and environmental protection, and practices are not harmonised within the study area (Figure 3c). For example, it is not always apparent whether any resource recovery would be considered as mineral extraction, waste management or remediation, all of which have different regulatory regimes in place. Therefore, it is rarely clear which stakeholders would need to be consulted to examine the potential of resource recovery, and many different regulations could apply, making the permitting process less transparent and potentially much more costly and protracted. 
Table 3. Key "basic" valorisation parameters (Pa.)—data availability in different EU countries (AV—Available, NA—Not Available, NAS—Not Assessed).

\begin{tabular}{|c|c|c|c|c|c|c|c|}
\hline Pa. & France & Spain & Italy & UK & Hungary & Slovenia & Portugal \\
\hline B1 & $\mathrm{AV}$ only for some sites & $\mathrm{AV}$ as short description & $\begin{array}{l}\text { AV for most of the } \\
\text { sites, detailed for some }\end{array}$ & $\mathrm{AV}(1)$ & $\begin{array}{l}\mathrm{AV} \text { only in mine closure } \\
\text { reports }\end{array}$ & $\begin{array}{l}\text { AV as short description } \\
\text { of history of mining site }\end{array}$ & $\begin{array}{l}\mathrm{AV} \text { as short description } \\
\text { of history of mining site }\end{array}$ \\
\hline B2 & $\begin{array}{c}\mathrm{AV} \text {, data quality } \\
\text { depends on potential } \\
\text { risk }\end{array}$ & AV & $\begin{array}{l}\mathrm{AV} \text { if provided by } \\
\text { Regional Geological } \\
\text { Survey }\end{array}$ & $\begin{array}{l}\text { NA in inventory, but in } \\
\text { various publications }\end{array}$ & $\begin{array}{l}\text { Estimation, AV in } \\
\text { technical operation } \\
\text { plans or individual } \\
\text { survey reports }\end{array}$ & Estimation & $\mathrm{AV}$ \\
\hline B3 & NAS & AV for larger mines & NA & NA & NA & AV for high risk sites & $\mathrm{AV}$ in selected sites \\
\hline B4 & $\begin{array}{l}\text { AV for high risk sites } \\
\text { with ongoing } \\
\text { remediation }\end{array}$ & NA & NA & $\begin{array}{l}\text { NA in inventory, but in } \\
\text { various publications }\end{array}$ & NA & NA & Visual estimation \\
\hline B5 & $\mathrm{AV}$ for high-risk sites (2) & $\mathrm{AV}(3)$ & $\begin{array}{l}\text { AV for deposits } \\
\text { investigated with } \\
\text { ARAGNA method } \\
\text { (Sardinia) }\end{array}$ & $\begin{array}{l}\mathrm{AV} \text { as part of the } \\
\text { methodology report }\end{array}$ & NA & AV & $\mathrm{AV}$ for remediated sites \\
\hline B6.1 & $\begin{array}{l}\text { AV for potential } \\
\text { high-risk sites }\end{array}$ & $\mathrm{AV}$ & $\mathrm{AV}$ & $\begin{array}{l}\mathrm{AV} \text {, based on risk } \\
\text { assessment }(4)\end{array}$ & $\mathrm{AV}$ & $\mathrm{AV}$ for high risk sites & $\begin{array}{l}\text { AV for active mines and } \\
\text { remediated sites }\end{array}$ \\
\hline B6.2 & $\begin{array}{l}\text { AV for high risk sites } \\
\text { with ongoing } \\
\text { remediation }\end{array}$ & $\mathrm{AV}$ & AV & $\begin{array}{l}\mathrm{AV} \text {, based on risk } \\
\text { assessment (4) }\end{array}$ & $\mathrm{AV}$ & $\mathrm{AV}$ for high risk sites & $\begin{array}{l}\mathrm{AV} \text { for active mines and } \\
\text { remediated sites }\end{array}$ \\
\hline B6.3 & $\begin{array}{l}\text { AV for potential } \\
\text { high-risk sites }\end{array}$ & AV & AV & $\begin{array}{l}\mathrm{AV} \text {, based on risk } \\
\text { assessment }(4)\end{array}$ & AV & $\mathrm{AV}$ for high risk sites & $\begin{array}{l}\mathrm{AV} \text { for active mines and } \\
\text { remediated sites }\end{array}$ \\
\hline B6.4 & $\begin{array}{l}\mathrm{AV} \text { for high risk sites } \\
\text { with ongoing } \\
\text { remediation }\end{array}$ & $\mathrm{AV}$ & AV & $\begin{array}{l}\mathrm{AV} \text {, based on risk } \\
\text { assessment (4) }\end{array}$ & AV & $\mathrm{AV}$ for high risk sites & $\begin{array}{l}\mathrm{AV} \text { for active mines and } \\
\text { remediated sites }\end{array}$ \\
\hline B6.5 & $\begin{array}{l}\text { AV for potential } \\
\text { high-risk sites }\end{array}$ & AV & $\mathrm{AV}$ & $\begin{array}{l}\mathrm{AV} \text {, based on risk } \\
\text { assessment (4) }\end{array}$ & $\mathrm{AV}$ & $\mathrm{AV}$ for highly risk sites & $\mathrm{AV}$ for risk sites \\
\hline B6.6 & $\begin{array}{l}\text { AV for high risk sites } \\
\text { with ongoing } \\
\text { remediation }\end{array}$ & NAS & $\begin{array}{l}\text { AV for specific sites } \\
\text { within the } \\
\text { remediation projects }\end{array}$ & $\begin{array}{l}\text { Based on risk } \\
\text { assessment ( } 4 \text { ) }\end{array}$ & NAS & NAS & $\begin{array}{l}\mathrm{AV} \text {, but possibly } \\
\text { confidential }\end{array}$ \\
\hline B7.1 & $\begin{array}{l}\text { AV for high risk sites } \\
\text { with ongoing } \\
\text { remediation }\end{array}$ & NAS & NAS & NA & AV for selected deposits & NAS & NAS \\
\hline B7.2 & NA & $\mathrm{AV}$ & $\mathrm{AV}$ & NA & $\mathrm{AV}$ & $\mathrm{AV}$ for risk sites & $\mathrm{AV}$ for risk sites \\
\hline
\end{tabular}


Table 3. Cont.

\begin{tabular}{|c|c|c|c|c|c|c|c|}
\hline Pa. & France & Spain & Italy & UK & Hungary & Slovenia & Portugal \\
\hline B8.1 & $\begin{array}{l}\text { AV for sites with no } \\
\text { responsible owner }\end{array}$ & NAS & $\begin{array}{l}\text { Data in the } \\
\text { environmental } \\
\text { protection and land } \\
\text { use plans }\end{array}$ & $\begin{array}{l}\text { NA, but held in } \\
\text { BRITPITS and/or the } \\
\text { Land Registry }\end{array}$ & $\mathrm{AV}$ for operating mines & $\begin{array}{l}\text { Information is } \mathrm{AV} \text { in } \\
\text { land register }\end{array}$ & $\mathrm{AV}$ \\
\hline B8.2 & $\begin{array}{l}\text { According to Mining } \\
\text { legislation }\end{array}$ & NAS & $\begin{array}{l}\text { Depending on land } \\
\text { use restrictions and } \\
\text { site hazard } \\
\text { characterisation, } \\
\text { involving local and } \\
\text { national authorities }\end{array}$ & $\begin{array}{l}\text { Mineral extraction is } \\
\text { subject to planning - } \\
\text { likely to be complicated } \\
\text { as may fall under } \\
\text { environmental } \\
\text { regulation }\end{array}$ & $\begin{array}{l}\text { According to Mining } \\
\text { legislation }\end{array}$ & $\begin{array}{l}\text { Depending on land use } \\
\text { restrictions and site } \\
\text { hazard characterisation, } \\
\text { involving local and } \\
\text { national authorities }\end{array}$ & $\begin{array}{l}\text { Mine waste are not } \\
\text { classified as waste in the } \\
\text { Portuguese } \\
\text { environmental law }\end{array}$ \\
\hline B8.3 & $\begin{array}{l}\text { According to Mining } \\
\text { legislation }\end{array}$ & NAS & $\begin{array}{l}\text { Depending on land } \\
\text { use restrictions and } \\
\text { site hazard } \\
\text { characterisation, } \\
\text { involving local and } \\
\text { national authorities }\end{array}$ & $\begin{array}{l}\text { There may be land use } \\
\text { restrictions which could } \\
\text { include cultural or } \\
\text { ecological designations } \\
\text { associated with past } \\
\text { mining }\end{array}$ & $\begin{array}{l}\text { According to Mining } \\
\text { legislation }\end{array}$ & $\begin{array}{l}\text { Determined in national } \\
\text { and municipality spatial } \\
\text { plans }\end{array}$ & $\begin{array}{c}\text { Determined in national } \\
\text { and municipality spatial } \\
\text { plans }\end{array}$ \\
\hline B8.4 & $\begin{array}{l}\text { If reprocessing includes } \\
\text { activities outside the } \\
\text { scope of mining } \\
\text { regulations }\end{array}$ & NAS & $\begin{array}{c}\text { Depending on land } \\
\text { use restrictions and } \\
\text { site hazard } \\
\text { characterisation, } \\
\text { involving local and } \\
\text { national authorities }\end{array}$ & $\begin{array}{l}\text { Waste management and } \\
\text { pollution control } \\
\text { regulations as well as } \\
\text { those protecting the } \\
\text { natural environment } \\
\text { and cultural assets }\end{array}$ & $\begin{array}{l}\text { If reprocessing includes } \\
\text { activities outside the } \\
\text { scope of mining } \\
\text { regulations }\end{array}$ & $\begin{array}{l}\text { Depending on land use } \\
\text { restrictions and site } \\
\text { hazard characterisation, } \\
\text { involving local and } \\
\text { national authorities }\end{array}$ & $\begin{array}{l}\text { If reprocessing includes } \\
\text { activities outside the } \\
\text { scope of mining } \\
\text { regulations }\end{array}$ \\
\hline B9.1 & Data in Table 1 & & & & & & \\
\hline B9.2 & National & National & National & National & National and English & National & National \\
\hline
\end{tabular}

(1) AV, but with cross-referencing to BRITPITS which details the type of mine (open cast, underground) but not the technology. (2) A guide with a methodology has been published [46]. (3) A guide with a methodology has been published [34]. (4) This information is not contained within mine waste inventory, but is available for some sites in other reports. 
Table 4. Key "metal-centric" valorisation parameters—data availability in different EU countries (AV—Available, NA—Not Available, NAS—Not Assessed).

\begin{tabular}{|c|c|c|c|c|c|c|c|}
\hline Pa. & France & Spain & Italy & UK & Hungary & Slovenia & Portugal \\
\hline M10.1 & $\begin{array}{l}\text { AV for high risk sites } \\
\text { with ongoing } \\
\text { remediation }\end{array}$ & $\mathrm{AV}$, not public & $\begin{array}{l}\text { AV for investigated } \\
\text { sites }\end{array}$ & $\begin{array}{l}\text { NA, but AV for a limited } \\
\text { number of mines in } \\
\text { other documents }\end{array}$ & $\mathrm{AV}$ & $\mathrm{AV}$ & $\begin{array}{l}\mathrm{AV} \text { for active sites and } \\
\text { selected remediated sites }\end{array}$ \\
\hline M10.2 & AV & $\mathrm{AV}$, not public & $\begin{array}{l}\text { AV for investigated } \\
\text { sites }\end{array}$ & NA, as above & $\begin{array}{l}\text { NA, only for specific } \\
\text { sites in other reports }\end{array}$ & $\begin{array}{l}\text { AV for high risk } \\
\text { sites }\end{array}$ & $\begin{array}{l}\text { AV for active and selected } \\
\text { remediated sites }\end{array}$ \\
\hline M10.3 & $\begin{array}{l}\mathrm{AV} \text { for high risk sites } \\
\text { with ongoing } \\
\text { remediation }\end{array}$ & $\mathrm{AV}$, not public & $\begin{array}{l}\text { AV for investigated } \\
\text { sites }\end{array}$ & NA, as above & $\begin{array}{l}\text { AV for red mud tailings } \\
\text { and for other sites } \\
\text { containing PTEs }\end{array}$ & $\begin{array}{l}\text { AV for high risk } \\
\text { sites }\end{array}$ & $\begin{array}{l}\mathrm{AV} \text { for active and selected } \\
\text { remediated sites }\end{array}$ \\
\hline M11.1 & $\begin{array}{l}\mathrm{AV} \text { for high risk sites } \\
\text { with ongoing } \\
\text { remediation }\end{array}$ & $\mathrm{AV}$, not public & $\begin{array}{l}\text { AV for investigated } \\
\text { sites }\end{array}$ & NA, as above & AV & $\begin{array}{l}\text { Visual estimation } \\
\text { for some sites }\end{array}$ & $\begin{array}{l}\mathrm{AV} \text { for active and selected } \\
\text { remediated sites }\end{array}$ \\
\hline M11.2 & $\begin{array}{l}\text { AV for high risk sites } \\
\text { with ongoing } \\
\text { remediation }\end{array}$ & NAS & $\begin{array}{l}\text { AV for investigated } \\
\text { sites }\end{array}$ & NA, as above & NAS & NAS & $\mathrm{AV}$ for active sites \\
\hline M11.3 & $\begin{array}{l}\text { AV for high risk sites } \\
\text { with ongoing } \\
\text { remediation }\end{array}$ & $\begin{array}{c}\mathrm{pH} \text { and electrical } \\
\text { conductivity only, not } \\
\text { public }\end{array}$ & $\begin{array}{l}\mathrm{AV} \text { for investigated } \\
\text { sites }\end{array}$ & NA, as above & NAS & NAS & $\mathrm{AV}$ for active sites \\
\hline
\end{tabular}


Table 5. Key "material-centric" valorisation parameters—data availability in different EU countries (AV—Available, NA—Not Available, NAS—Not Assessed).

\begin{tabular}{|c|c|c|c|c|c|c|c|}
\hline Pa. & France & Spain & Italy & UK & Hungary & Slovenia & Portugal \\
\hline C10.1 & NAS & NAS & $\begin{array}{l}\mathrm{AV} \text { as potential } \\
\text { residues }\end{array}$ & $\begin{array}{l}\text { NA, but AV for a limited } \\
\text { number of mines in } \\
\text { other documents }\end{array}$ & NAS & NAS & NAS \\
\hline $\mathrm{C} 10.2$ & NAS & NAS & $\begin{array}{l}\mathrm{AV} \text { as potential } \\
\text { residues }\end{array}$ & $\mathrm{NA}$, as above & NAS & NAS & NAS \\
\hline C10.3 & NAS & NAS & $\begin{array}{l}\mathrm{AV} \text { as potential } \\
\text { residues }\end{array}$ & NA, as above & NAS & NAS & NAS \\
\hline $\mathrm{C} 10.4$ & NAS & $\mathrm{AV}$, not public & $\begin{array}{l}\mathrm{AV} \text { as potential } \\
\text { residues }\end{array}$ & NA, as above & AV for larger waste sites & AV for high risk sites & NAS \\
\hline C10.5 & NAS & NAS & $\begin{array}{l}\mathrm{AV} \text { as potential } \\
\text { residues }\end{array}$ & NA, as above & NAS & $\begin{array}{l}\text { Visual estimation for } \\
\text { some sites }\end{array}$ & NAS \\
\hline C11.1 & $\begin{array}{l}\text { AV for high risk sites with } \\
\text { ongoing remediation }\end{array}$ & NAS & $\begin{array}{c}\text { AV for investigated } \\
\text { sites }\end{array}$ & NA, as above & NAS & NAS & NAS \\
\hline C11.2 & $\begin{array}{l}\text { AV for high risk sites with } \\
\text { ongoing remediation }\end{array}$ & $\mathrm{AV}$, not public & $\begin{array}{c}\mathrm{AV} \text { for investigated } \\
\text { sites }\end{array}$ & NA, as above & NAS & $\begin{array}{l}\text { Visual estimation for } \\
\text { some sites }\end{array}$ & NAS \\
\hline $\mathrm{C} 12.1$ & NAS & NAS & $\begin{array}{l}\text { AV for investigated } \\
\text { sites }\end{array}$ & NA, as above & NAS & NAS & NAS \\
\hline $\mathrm{C} 12.2$ & NAS & NAS & $\begin{array}{c}\mathrm{AV} \text { for investigated } \\
\text { sites }\end{array}$ & NA, as above & NAS & NAS & NAS \\
\hline
\end{tabular}


a

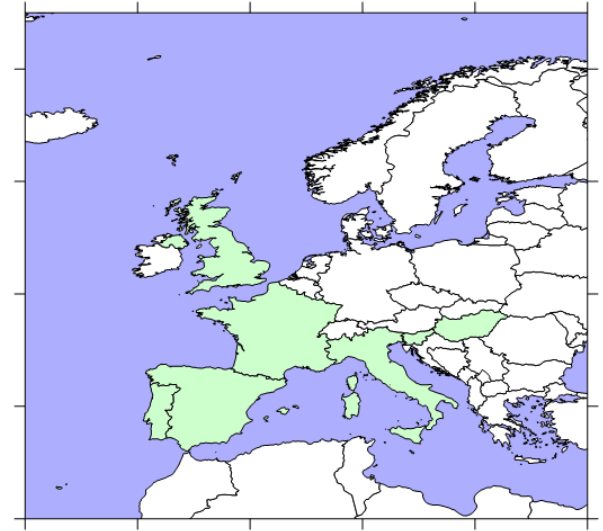

b

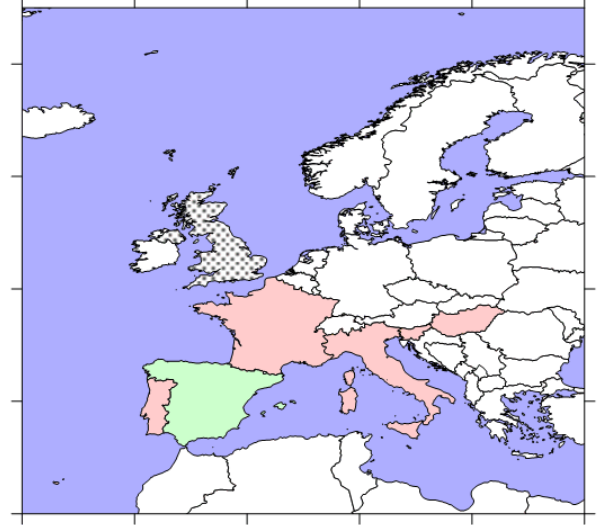

C

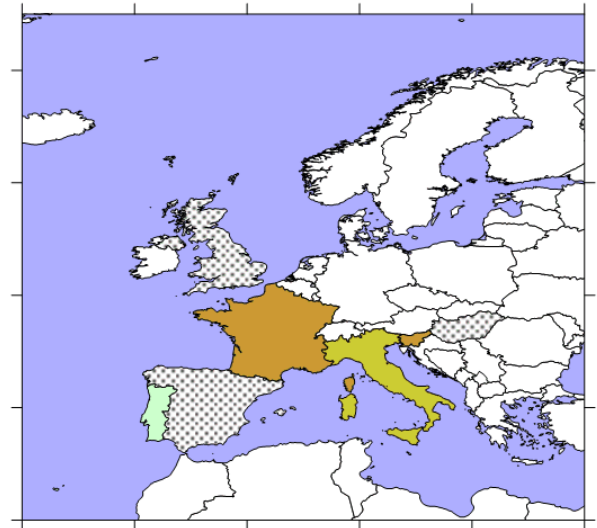

d

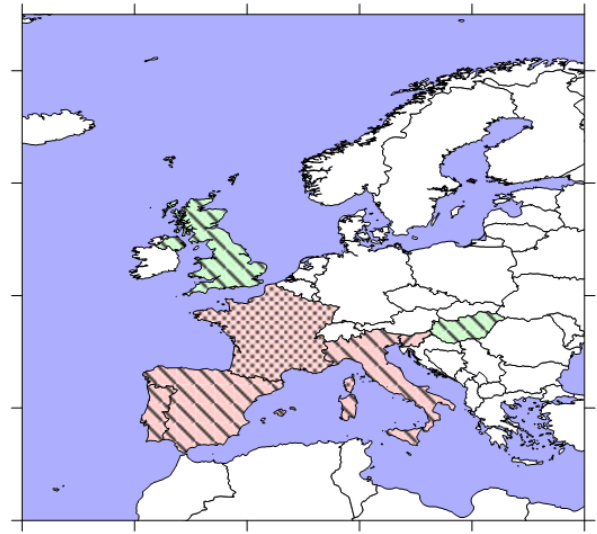

Main objective of creating national mining waste registries.

Legend:

Environmental protection

Future waste recycling

Availability of physical and chemical properties of mine waste in national registries.

\section{Legend:}

Only basic data

More detailed assessment for high-risk mine waste deposits

The same for all mine waste deposits

\section{Key legislation, regulating} mining waste reuse.

\section{Legend:}

Scattered (no key legislative act or depending on the circumstances)

Mining legislation

Environmental legislation

Land use + Environmental

\section{Data availability and} language.

\section{Legend:}

Data availability (foreground pattern)

not publicly available

7.7 publicly available locations with basic data (detailed data is not publicly available)

$V /$ detailed reports available on-line

Language (background color)

$\square$ in national language only

in national and English language

Figure 3. (a) The main country vision for creating national mine waste registries. (b) Availability of detailed mine waste deposit data. (c) Key legislation which regulates resource recovery from mine waste (simplification). (d) Data availability and language used in national mine waste registries. 
Data from Table 4 show that the key "metal-centric" and "material-centric" resource recovery valorisation parameters are generally available for larger and high-risk sites, but are mainly focused on the analysis of PTEs. However, the mine waste deposits could be very heterogeneous, depending on the history of ore extraction and processing, as well as the occurrence of secondary processes in the waste column, but the information on PTE levels are generally available only from surface materials, not only in the UK [45], but also elsewhere. This also limits the usefulness of mine waste registries as a source of information for metal extraction beyond providing only brief information in order to plan more detailed investigations. Another drawback is also that national mine waste registries generally do not contain information about metals that are not classified as PTEs. Many of such metals are regarded as critical elements today (e.g., Li, Ge or rare earth elements) and mine waste dumps could be an interesting source of these raw materials.

Even less information about mine waste is provided regarding the key "material-centric" valorisation parameters (Table 5). Except for a few cases from the Italian inventory, the information of the content of alkali ions, redox potential, silicon, organic substance, etc., was not assessed at all. The only exception is the levels of PTEs, measured in larger sites or sites with a higher environmental risk. Therefore, we can conclude that national mine waste registries are not a useful initial source of information to valorise mine waste for potential material-centric recovery (i.e., to produce construction materials), but do perhaps provide a basis for a further search for information from other sources (i.e., papers, reports, projects, archiver, etc.).

During the assessing of the specific datasets from the national registries, it also became evident that different countries had different data access policies (Figure 3d). While most countries provide information about the locations of mine waste deposits and basic characteristics, it is still very hard to access detailed reports, which contain the information needed for the potential assessment of resource recovery from mine waste. Even if such reports are publicly available, they cannot be found in one place, but could be scattered across different locations (i.e., web pages, libraries, etc.). Another potential barrier is language, where the information and reports are, with the only exception of Hungary, provided only in the national language. UK, France or Spain are, of course, a special case here because their languages can be regarded as world languages. However, this is not the case for smaller countries such as, for example, Slovenia or Portugal. This barrier can be overcome by hiring translation services, local experts or use electronic translator services, but the initial identification of potential future mine waste recycling projects by international companies can be made much easier if data are available in a commonly spoken language. Therefore, we can conclude that countries could also contribute to the use of mine waste registries outside the originally designated scope of environmental protection by placing searchable data online in one place, along with all non-confidential details, and to also make them available in English. This would be a significant step forward in providing mine waste data in the context of future resource recovery and reuse, and would move towards a more harmonised approach across the EU.

However, the French example represents the best practice in the sense of the amount of data contained in the national mine waste inventory. Investigations on closed or abandoned mine sites and mine waste follow a consistent national framework in France. Sites with a responsible owner are usually documented through the mine lease renunciation document, which establishes the respective obligations of the owner and of the administration. For the much larger number of sites without a responsible party, investigations are led by a public agency (GEODERIS) to identify the potential risks at the site (mainly geotechnical and environmental) via a tiered approach. A first level of investigation on all sites leads to a selection of sites based on potential risks (ranking) that require further assessment. Subsequent investigations (second level) are then performed at these sites where an evidence of risk was demonstrated or in cases where actual damage is recognised. The highest level of investigation is where a significant risk of adverse health or environmental impact was identified in the vicinity of the site. It can even be applied to local housing ("maison sur depot") [32] when the property is located on waste. Even if these investigations are led by a specialised public agency, they are carried out on behalf 
of, and funded by, the administration, which keeps their results out of the public domain until the full cycle of investigations has been completed. This can result in long delays in the disclosure of site-scale primary information such as waste data.

Within the analysed countries in this study, the UK is a special case. The national mine waste inventories contain only basic data, based on the environmental or human health risk. However, much more data can be obtained from the British Geological Survey which holds a national dataset (BRITPITS) that includes information on every mine location (as point data) in the UK [36]. However, the mine waste inventories have been compiled, often based on this dataset, by the individual regulatory agencies (Environment Agency, The Scottish Government and the Northern Ireland Department of Environment). The methods used in England and Wales, and Scotland are similar, whereas those used in Northern Ireland differ in their approach. In England and Wales, and Scotland, the data from BRITPITs have been used in conjunction with information held by local authorities and to assess the risk from closed and abandoned mines using a source-pathway-receptor approach. These included leaching, erosion, windblown dust and dermal contact/ingestion, providing a pathway for pollution, heap, dam or pond failure, resulting from instability and the smoke, heat, dust and gases caused by flammable materials. The receptors included human health, surface and groundwater, protected ecological systems, property, crops and livestock. This was tested against a series of criteria for serious environmental risk (e.g., based on Environmental Quality Standards for surface water quality, meeting the definition of contaminated land). Potential sites were sought via a proforma that was sent to all local authorities requesting information on the sites in their areas with the potential for inclusion on the inventory. This was used in conjunction with information on the location and volume of mine wastes associated with abandoned mines, as estimated by the British Geological Survey [37], and information on water quality taken from a range of sources to develop the inventory. The approach in Northern Ireland was similar except that a hazard quotient was used in the risk assessment process when examining the source-pathway-receptor linkage [38].

Based on the findings of this study, a recommendation for policy makers and regulative bodies would be to make all data which are contained within national mine waste registries available online (if not yet done), together with at least the basic data in English. An EU-wide assessment of the resources available in mine wastes is needed to inform decision makers on the management of mineral resources, whether to prioritise new, efficient methods for extracting resources from wastes or changing policy to simplify resource recovery in the case of expressed interest from the private sector. The detailed information being compiled on a case-by-case basis does not enable a national or EU-wide strategic assessment of the potential value in these sites and whether they could alleviate some of the concerns regarding raw material supply security from domestic sources. Currently, case-by-case data that have been collected make a persuasive case for resource recovery, especially where sites are causing adverse environmental impacts, and the potential release of land being used for waste storage and resource recovery can be combined with site remediation. Without this EU-wide assessment, it is very hard to assess the potential for raw material supply from mine waste deposits. A shift of scope from environmental protection towards including the consideration of material recovery from abandoned mine waste sites is needed in any possible future nation- or EU-wide mine waste data collection. In the case of potential new data collection or national mine waste registry updates, it is suggested that the collection of the following information should be prioritised first: a more detailed assessment of the quantities of specific mine wastes deposits and their homogeneity, the levels of commodity elements in mine wastes, the determination of parameters describing site accessibility and other missing parameters from the "basic" group of parameters. It is also recommended that a case-wise assessment should be made to collect the parameters needed for the consideration of metal-centric or/and material-centric mine waste valorisation and materials recovery.

A further recommendation to those exploring the potential for resource recovery from mine wastes would be to use these national mine waste registries to find basic information about potential 
suitable sites, and then consult other sources of information (geological surveys, regional or local authorities) to obtain more data in order to preliminarily valorise specific mine waste deposit sites.

\section{Conclusions}

In this study, we examined national mine waste registries from seven European member states (France, Hungary, Italy, Portugal, Slovenia, Spain and United Kingdom), developed in accordance with the Mine Waste Directive (2006/21/EC), for their potential use as an initial source of information for the valorisation of specific mine waste deposits for material recovery. The amount of data which have been collected and is now available varies from country to country. Due to the original motivation for their collection being the prevention of PTEs' mobilisation into the environment and the long-term stability of mine waste deposits, potential future resource recovery or reuse was not considered as the priority. This is reflected in the data content, which makes the national mine waste inventories only a potential source of basic information, i.e., location of mine waste, main commodity or estimation of tailing deposit volume. Only limited or even no information is provided in regard to the homogeneity, grain size distribution or content of substances which are not regarded as pollutants, but are important for the potential future use of such materials (alkali and alkaline earth ions, moisture, redox state, etc.). In most cases, there is not sufficient enough data that can be used in assessing projects for resource recovery from national mine waste registries of EU countries. Further, the legislative, regulative and policy frameworks for material recovery from mine waste are not homogeneous across the EU. The results of this study can be useful for policy makers that could benefit from it by obtaining the most critical nation-wide mine waste valorisation data gaps and determine the steps forward, while the metallurgical and extractive industry could find the first glimpse of data availability for a set of EU countries to obtain information about mine waste potentials, especially in the light of the latest developments in tailings and materials reprocessing (including hydrometallurgical processes, bioleaching, in-situ leaching and others).

Author Contributions: Conceptualization, all authors; methodology, G.Ž.; validation, all authors; formal analysis, G.Ž.; investigation, G.Ž., B.L., A.-M.M., C.C., D.S., P.C., K.S. and M.T.C.; resources, all authors; data curation, G.Ž.; writing—original draft preparation, G.Ž.; writing-review and editing, all authors; visualization, G.Ž., C.C.; supervision, T.C.; project administration, T.C.; funding acquisition, T.C. with contributions from all authors. All authors have read and agreed to the published version of the manuscript.

Funding: This study was conducted as a part of the MINEA Cost action, CA15115, "Mining the European Anthroposphere", as a part of activities within working group no. 2.1, which covers the travel expenses. Working hour expenses are covered by the following organisations: The Slovenian Research Agency (research core funding No. P1-0025 "Mineral resources"), BRGM, France, (post-mining research activities, Ministry in charge of the Environment), CERENA, Portugal, (through the strategic Project UID/ECI/04028/2019) and the Natural Environment Research Council /Economic and Social Research Council-funded 'INSPIRE: IN Situ Processes In Resource Extraction from waste repositories' project (Grant Reference NE/L013916/1).

Acknowledgments: Authors would like to specially thank Dimitrios Panias from the School of Mining \& Metallurgical Engineering, Greece, and Patrick d'Hugues from BRGM, France, for sharing their mine waste valorisation experiences with the group, and Ulrich Kral from TU Wien for coordinating the MINEA cost action and encouraging the publication. Special regard goes to three reviewers for their valuable comments, which improved the manuscript.

Conflicts of Interest: The authors declare that they have no known competing financial interests or personal relationships that could have appeared to influence the work reported in this paper.

\section{References}

1. Coulson, M. The History of Mining: The Events, Technology and People Involved in the Industry that Forged the Modern World; Harriman House Ltd.: Hampshire, UK, 2012.

2. Mudd, G.M. The Sustainability of Mining in Australia: Key Production Trends and Their Environmental Implications for the Future; Research Report No. RR5; Department of Civil Engineering, Monash University: Monash, Australia, 2009. 
3. Habashi, F. Metallurgy, History of. In Reference Module in Materials Science and Materials Engineering; Saleen, $\mathrm{H}$., Ed.; Elsevier: Oxford, UK, 2017; pp. 1-6.

4. Zepf, V.; Simmons, J.; Reller, A.; Rennie, C.; Ashfield, M. Materials Critical to the Energy Industry. An Introduction, 2nd ed.; British Petroleum: London, UK, 2014.

5. Endangered Elements. Available online: https://www.acs.org/content/acs/en/greenchemistry/researchinnovation/endangered-elements.html (accessed on 23 April 2020).

6. The 2017 List of Critical Raw Materials for the EU. Available online: https://eur-lex.europa.eu/legal-content/ EN/TXT/?uri=CELEX:52017DC0490 (accessed on 27 April 2020).

7. Lemière, B. Mining the waste: Prospecting valuable residues optimising processes with modern technology, sustainably remediating legacy sites. In Proceedings of the conference 2nd Eurasia-MENA Mining Summit, Istanbul, Turkey, 16-17 June 2012.

8. Binnemans, K.; Pontikes, Y.; Jones, P.T.; Van Gerven, T.; Blanpain, B. Recovery of rare earths from industrial waste residues: A concise review. In Proceedings of the Third International Slag Valorization Symposium, KU Leuven, Belgium, 19-20 March 2013; Malfliet, A., Jones, P.T., Binnemans, K., Cizer, Ö., Fransaer, J., Yan, P., Pontikes, Y., Guo, M., Blanpain, B., Eds.; 2013; pp. 191-205.

9. Falagán, C.; Grail, B.M.; Johnson, B. New approaches for extracting and recovering metals from mine tailings. Min. Eng. 2017, 106, 71-78. [CrossRef]

10. Matinde, E.; Simate, G.S.; Ndlovu, S. Mining and metallurgical wastes: A review of recycling and re-use practices. J. S. Afr. Inst. Min. Metall. 2018, 118, 825-844. [CrossRef]

11. Valderrama, I.; Santander, M.; Paiva, M.; Rubio, J. Modified-three-product-column (3PC) flotation of copper-gold particles in a rougher feed and tailings. Min. Eng. 2011, 24, 1397-1401. [CrossRef]

12. Sapsford, D.J.; Cleall, P.J.; Harbottle, M.J. In situ resource recovery from waste repositories: Exploring the potential for mobilisation and capture of metals from anthropogenic ores. J. Sustain. Metall. 2017, 3, 375-392. [CrossRef]

13. Peppicelli, C.; Harbottle, M.J.; Sapsford, D.J.; Cleall, P.J. Changes in metal speciation and mobility during electrokinetic treatment of industrial wastes: Implications for remediation and resource recovery. Sci. Total Environ. 2018, 624, 1488-1503. [CrossRef] [PubMed]

14. Bellenfant, G.; Guezennec, A.G.; Bodenan, F.; D’Hugues, P.; Cassard, D. Re-processing of mining waste: Combining environmental management and metal recovery? In Mine Closure 2013, Proceedings of the Eighth International Seminar on Mine Closure, Vina del Mar, Chile, 5-7 December 2013; Fourie, A.B., Tibbett, M., Eds.; Australian Centre for Geomechanics: Perth, Australia, 2013; pp. 571-582.

15. Ndlovu, S.; Simate, G.S.; Matinde, E. Waste Production and Utilization in the Metal Extraction Industry; CRC Press: Boca Raton, FL, USA, 2017; p. 512.

16. Directive 2006/21/EC of the European Parliament and of the Council of 15 March 2006 on the Management of Waste from Extractive Industries and Amending Directive 2004/35/EC-Statement by the European Parliament, the Council and the Commission. Available online: https://eur-lex.europa.eu/legal-content/EN/ TXT/?uri=CELEX\%3A32006L0021 (accessed on 24 April 2020).

17. Grimalt, J.O.; Ferrer, M.; Macpherson, E. The mine tailing accident in Aznalcollar. Sci. Total Environ. 1999, 242, 3-11. [CrossRef]

18. McDermott, R.K.; Sibley, J.M. The Aznalcóllar tailings dam accident-A case study. Min. Resour. Eng. 2000, 09, 101-118. [CrossRef]

19. Report of the International Task Force for Assessing the Baia Mare Accident; ICPDR: Brussels, Belgium, 2000; Available online: https:/reliefweb.int/report/hungary/report-international-task-force-assessing-baia-mareaccident (accessed on 5 February 2019).

20. The Raw Materials Initiative-Meeting Our Critical Needs for Growth and Jobs in Europe. Available online: https://eur-lex.europa.eu/LexUriServ/LexUriServ.do?uri=COM:2008:0699:FIN:en:PDF (accessed on 24 April 2020).

21. Panagiotopoulou, C.; Gaki, A.; Balomenos, E.; Taxiarchou, M.; Panias, D.; Paspaliaris, I.; Aggelopoulos, P. Valorisation of Extractive Industries' Wastes. In Proceedings of the OPMR2016-Opportunities in Processing of Metal Resources in South East Europe, Budapest, Hungary, 28-30 November 2016; pp. 201-211.

22. Garbarino, E.; Orveillon, G.; Saveyn, H.; Barthe, P.; Eder, P. Best Available Techniques (BAT) Reference Document for the Management of Waste from Extractive Industries in Accordance with Directive 2006/21/EC; Report No. EUR 28963 EN; Publication Office of the European Union: Luxembourg, 2018; p. 692. 
23. Blengini, G.A.; Mathieux, F.; Mancini, L.; Nyberg, M.; Cavaco Viegas, H.M. (Eds.) Recovery of Critical and Other Raw Materials from Mining Waste and Landfills: State of Play on Existing Practices; EUR 29744 EN; Publications Office of the European Union: Luxembourg, 2019.

24. Bodenan, F.; Guezennec, A.G.; Beaulieu, M.; Bellenfant, G.; Lemière, B.; Catherine, L.; Save, M. Re-Processing of mine tailings: Discussion on case studies. In Proceedings of the 13th SGA Biennal Meeting, Nancy, France, 24-27 August 2015.

25. Dino, G.A.; Rossetti, P.; Biglia, G.; Sapino, M.L.; Di Mauro, F.; Sarkka, H.; Coulon, F.; Gomes, D.; Parejo-Bravo, L.; Aranda, P.Z.; et al. Smart Ground Project: A New Approach to Data Accessibility and Collection for Raw Materials and Secondary Raw Materials in Europe. Environ. Eng. Manag. J. 2017, 16, 1673-1684. [CrossRef]

26. Management of Mining, Quarrying and Ore Processing Waste in the European Union. Study Made for DG Environment, European Commission. BRGM/RP-50319-FR. December 2001. Available online: https: //ec.europa.eu/environment/waste/studies/mining/0204finalreportbrgm.pdf (accessed on 5 February 2019).

27. International Reporting Template for the Public Reporting of Exploration Targets, Exploration Results, Mineral Resources and Mineral Reserves. November 2019. Available online: http://www.crirsco.com/ templates/CRIRSCO_International_Reporting_Template_November_2019.pdf (accessed on 5 February 2019).

28. Australasian Code for Reporting of Exploration Results, Mineral Resources and Ore Reserves (The JORC Code 2012 Edition). Available online: http://www.jorc.org/docs/JORC_code_2012.pdf (accessed on 5 February 2019).

29. PERC Reporting Standard. Pan-European Standard for Reporting of Exploration Results, Mineral Resources and Reserves ("The PERC Reporting Standard"). 2017. Available online: http://www.vmine.net/PERC/ documents/PERC\%20REPORTING\%20STANDARD\%202017.pdf (accessed on 5 February 2019).

30. United Nations Framework Classification for Fossil Energy and Mineral Reserves and Resources 2009 Incorporating Specifications for Its Application; ECE Energy Series; No. 42; UN: New York, NY, USA, 2014; Available online: https://doi.org/10.18356/a9e6af6c-en (accessed on 5 February 2019).

31. GEODERIS. Propositions Méthodologiques sur les Conditions de Mise en Oeuvre de la Démarche D'interprétation de L'état des Milieux au Contexte D'après-Mine; Report N2015/014DE-15NAT24080; GEODERIS: Metz, France, 2015. (In French)

32. GEODERIS. Suites Données à L'inventaire DDIE Actualisation Méthodologique Introduction de la Catégorisation des Secteurs; Report N2016/025DE-16NAT24010; GEODERIS: Metz, France, 2017. (In French)

33. Charles, N.; Dupuy, J.-J.; Christmann, P.; Galin, R.; Guillon, D. Industrie Minérale et Activité Minière en France. Collection «La Mine en France». Tome 1, 25p, 5 figures, 2 tables. 2017. Available online: http://www.mineralinfo.fr/sites/default/files/upload/tome_01_industrie_mineraleactivite_miniere_ final24032017.pdf (accessed on 10 May 2020).

34. Jiménez, A.M.; Vadillo, L.; Rodríguez Pacheco, R.L.; Fernández Naranjo, F.J.; Arranz-González, J.C.; Alberruche, E.; Rodriguez Gomez, V. Metodología Para la Realización de un Inventario de Instalaciones de Residuos Mineros Cerradas o Abandonadas; Instituto Geológico y Minero de España (IGME): Madrid, Spain, 2014; p. 206.

35. Serra, M.; Andrisani, M.G. Inventario Nazionale delle Strutture di Deposito di Rifiuti Estrattivi, Chiuse o Abbandonate di Tipo A; Report No. GEO 2017/RA/01; ISPRA: Rome, Italy, 2017. Available online: http: //www.isprambiente.gov.it/files/miniere/Inventario_Aggiornamento_2017.pdf (accessed on 5 February 2019).

36. Cameron, D.G. Use Guide for the BRITPITS GIS Dataset; Open Report OR/13/016; British Geological Survey: Keyworth, UK, 2012.

37. Palumbo-Roe, B.; Colman, T. The Nature of Waste Associated with Closed Mines in England and Wales; Open Report OR/10/14; British Geological Survey: Keyworth, UK, 2010.

38. Palumbo-Roe, B.; Linley, K.; Cameron, D.; Mankelow, J. Inventory of Closed Mine Waste Facilities in Northern Ireland, Phase 2, Assessment; Report CR/14/031N; British Geological Survey: Nottingham, UK, 2014.

39. Inventory of Closed Mining Waste Facilities, Version 2 (UK Environment Agency). Available online: https://assets.publishing.service.gov.uk/government/uploads/system/uploads/attachment_data/file/ 288582/LIT_6797_7d390c.pdf (accessed on 5 February 2019).

40. Inventory of Closed Mining Waste Facilities (Scottish Government). Available online: https://www.gov.scot/binaries/ content/documents/govscot/publications/advice-and-guidance/2015/01/closed-mining-waste-facilities-list/ documents/fe847c5d-896f-4d92-8c11-ab1341538a90/fe847c5d-896f-4d92-8c11-ab1341538a90/govscot:document/ (accessed on 5 February 2019). 
41. Kiss, J.; Jordán, G. Inventory and Risk Classification of Closed Mine Waste Facilities for Hungary; Version No. 2; MBFH-ELGI-MÁFI: Budapest, Hungary, 2012.

42. Gosar, M.; Šajn, R.; Miler, M. Izdelava Popisa Zaprtih Objektov za Ravnanje z Odpadki iz Rudarskih in Drugih Dejavnosti Izkoriščanja Mineralnih Surovin—Poročilo 1. Faze Projekta; Geological Survey of Slovenia: Ljubljana, Slovenia, 2013. (In Slovene)

43. Gosar, M.; Šajn, R.; Miler, M. Izdelava Popisa Zaprtih Objektov za Ravnanje z Odpadki iz Rudarskih in Drugih Dejavnosti Izkoriščanja Mineralnih Surovin—Poročilo 2. Faze Projekta; Geological Survey of Slovenia: Ljubljana, Slovenia, 2013. (In Slovene)

44. Gosar, M.; Šajn, R.; Miler, M. Izdelava Popisa Zaprtih Objektov za Ravnanje z Odpadki iz Rudarskih in Drugih Dejavnosti Izkoriščanja Mineralnih Surovin—Poročilo 3. Faze Projekta; Geological Survey of Slovenia: Ljubljana, Slovenia, 2014. (In Slovene)

45. Crane, R.A.; Sinnett, D.E.; Cleall, P.J.; Sapsford, D.J. Physicochemical composition of wastes and co-located landscape designations at legacy mine sites in south west England and Wales: Implications on resource potential. Resour. Conserv. Recycl. 2017, 123, 117-134. [CrossRef]

46. Méthodologie Nationale de Gestion des Sites et Sols Pollués. Ministère de l'Environnement, de l'Energie et de la Mer. Available online: http://ssp-infoterre.brgm.fr/sites/default/files/upload/documents/methodo_ssp_ 2017.pdf (accessed on 5 February 2019).

(C) 2020 by the authors. Licensee MDPI, Basel, Switzerland. This article is an open access article distributed under the terms and conditions of the Creative Commons Attribution (CC BY) license (http://creativecommons.org/licenses/by/4.0/). 